\title{
STUDI KOMPARASI HASIL BELAJAR SISWA DALAM PEMBELAJARAN MENULIS PANTUN DENGAN MENERAPKAN COOPERATIVE INTEGRATED READING AND COMPOSITION (CIRC) DAN KONVENSIONAL DI KELAS VII SMPN 4 KOTA BENGKULU
}

\author{
Okta Fernando, Suhartono, dan Agus Joko Purwadi \\ Program Studi Pendidikan Bahasa Indonesia \\ Jurusan Pendidikan Bahasa dan Seni \\ FKIP Universitas Bengkulu \\ oktafernando23@gmail.com
}

\begin{abstract}
Abstrak
Tujuan penelitian ini untuk mengetahui perbedaan menulis pantun menggunakan Cooperative Integrated Reading and Composition $(\mathrm{CIRC})$ dengan pembelajaran Konvensional siswa kelas VII SMPN 4 Kota Bengkulu tahun ajaran 2017/2018. Metode yang digunakan dalam penelitian ini adalah metode eksperimen menggunakan bentuk desain Quasi Eksperimental dengan menggunakan Intact-group comparison. Data dalam penelitian ini adalah deskripsi hasil tes kemampuan menulis pantun kelas eksperimen (CIRC) dan kelas kontrol (model Konvensional). Penelitian ini dilakukan secara bergantian antara dua kelas VII 5 (eksperimen) dan VII 6 (kontrol) yang semuanya berjumlah 64 siswa. Teknik pengumpulan data menggunakan teknik tes. Hasil penelitian dengan menggunakan rumus t-test terdapat perbedaan perhitungan dan temuan pada kemampuan menulis pantun siswa menggunakan model CIRC dan menggunakan model konvensional, uji t-test diperoleh hasil t-hitung 2,63. Nilai rata-rata untuk kelas eksperimen yang diperoleh siswa sebesar 90,5, masuk dalam kategori sangat baik dan nilai rata-rata untuk kelas kontrol yang diperoleh siswa sebesar 79,4, masuk dalam kategori baik, sehingga terdapat nilai rata-rata selisih antara kedua model senilai 9,8 pada hasil tes siswa.
\end{abstract}

Kata Kunci: Kemampuan menulis, pantun, CIRC

\begin{abstract}
The purpose of this research is to know the difference of Pantun writing using cooperative integrated reading and composition (CIRC) with Conventional learning of grade VII student of SMPN 4 Bengkulu City of academic year 2017/2018. The method used in this study is the experimental method using the Quasi Experimental design form using Intact-group comparison. The data in this study is a description of the ability to write the rhyme of the experimental class (CIRC) and the control class (Conventional models). This research was conducted alternately between two classes VII 5 (experiment) and VII 6 (control), all of which were 64 students. Technique of collecting data using test technique. Result of research by using t-test formula there are difference of calculation and findings on student Pantun writing ability using CIRC model and using conventional model, t-test result obtained by $t$-count 2,63 . The average value for the experimental class obtained by students was 90.5 , in the very good category and the average value for the control class obtained by students was 79.4, in the good category, so that there was an average difference between the two model worth 9.8 on student test results.
\end{abstract}

Keywords: Writing ability, pantun, CIRC 


\section{PENDAHULUAN}

Pembelajaran Bahasa Indonesia merupakan sebuah pembelajaran yang menekankan empat keterampilan berbahasa, salah satunya keterampilan menulis. Apabila keterampilan menulis siswa di sekolahnya baik, tentu sekolah tersebut mempunyai produksi karya-karya dan menjadi sebuah sekolah yang sangat produktif. Sejalan dengan itu, menurut Tarigan (2008:3) metode apapun yang digunakan dalam pengajaran bahasa, jelas bahwa tujuan utamanya ialah agar para pembelajar terampil atau mampu berbahasa.

Menulis merupakan sebuah ide atau gagasan yang dituangkan dalam sebuah tulisan. Sejalan dengan itu, menurut Iskandarwassid (2010:248) menulis merupakan suatu bentuk manifestasi kemampuan dan keterampilan berbahasa yang paling akhir dikuasai oleh pembelajaran bahasa setelah kemampuan mendengarkan, berbicara, dan membaca.

Pantun merupakan sebuah karya sastra yang termasuk ke dalam jenis puisi rakyat. Pantun masih terikat erat dengan kaidah dan aturan-aturan penulisan yang berlaku. Dalam pembelajaran Kurikulum 2013 ini, pantun masih dimasukkan dalam rencana pelaksanaan pembelajaran (RPP) dan dipakai dalam pembelajaran di sekolah, khususnya sekolah menengah pertama (SMP). Menulis pantun sendiri merupakan salah satu keterampilan yang tidak lahir secara alami melainkan dengan pembelajaran yang efektif dari penulis itu sendiri. Pantun juga merupakan suatu budaya dari salah satu suku yang ada di Indonesia dan mesti dilestarikan, sehingga dalam pembelajaran di kelas seorang guru harus memberikan suatu metode yang tepat untuk mengasah kemampuan siswa dalam menulis pantun. Namun sangat disayangkan, dewasa ini kebanyakan dari guru di sekolah dalam memaparkan pembelajaran pantun ini hanya sekedar teori dan kurangnya metode yang variatif di kelas, sehingga pembelajaran menulis pantun di kelas terkesan monoton dan membosankan. Apabila hal ini dibiarkan secara berlanjut, tanpa ada inovasi dari guru, maka dapat berdampak buruk bagi kemampuan siswa dalam pembelajaran menulis pantun.

Pembelajaran menulis puisi lama (pantun) ini membutuhkan sebuah daya imajinasi. Dalam pembelajaran yang ada pada kelas VII (tujuh) di sekolah menengah ini, rata-rata siswanya berumuran 13 sampai 15 tahun. Di usia ini potensi siswa untuk berkreasi dan berimajinasi masih sangat luas, sehingga untuk pembelajaran menulis pantun ini dapat dijadikan sebagai wadah siswa untuk menuangkan gagasan atau imajinasi-imajinasi yang ada dalam pikiran itu menjadi sebuah karya sastra yang indah.

Berdasarkan hasil observasi data hasil tes belajar siswa dan wawancara dengan guru yang mengajar di kelas VII SMP Negeri 4 Kota Bengkulu tahun ajaran 2017/2018 diperoleh informasi bahwa siswa pada pembelajaran menulis pantun menemukan kendala dalam menulis dan menyimpulkan isi pantun. Di kelas siswa masih diberikan pembelajaran yang kurang variatif. Guru hanya memberikan pembelajaran dalam menulis pantun yang relatif hanya menggunakan teori tanpa menggunakan metode yang kreatif dan variatif. Peran guru dalam kegiatan pembelajaran yang terlalu dominan, membuat pembelajaran yang dilaksanakan terkesan satu arah. Pembelajaran yang harusnya terpusat pada siswa justru sebaliknya. Dilihat dari pemaparan sistem pembelajaran yang dilakukan oleh guru tersebut dapat dipastikan masih bersifat konvensional. Sehingga membuat siswa tidak terlalu bersemangat serta imajinasi yang ada dalam pikiran kurang berkembang. 
CIRC (Cooperative Integrated Reading and Composition) adalah model pendekatan yang komprehensif untuk pembelajaran membaca dan menulis untuk kelas 2-8. Shoimin (2014:51) berpendapat bahwa model CIRC merupakan model pembelajaran khusus mata pelajaran bahasa dalam rangka membaca dan menemukan ide pokok, pokok pikiran, atau tema sebuah wacana. Ten pembelajaran modelCIRC ini juga merupakan suatu pembelajaran yang berfokus pada siswa. Kemudian, CIRC juga mempunyai kelebihan yang mampu membuat siswa memahami isi bacaan yang dapat diaplikasikan secara luas. Berdasarkan pemaparan di atas, menjadi landasan peneliti untuk meneliti kemampuan menulis pantun (puisi rakyat) dengan menggunakan model pembelajaran CIRC yang diharapkan dapat menunjukkan perbedaan yang signifikan dibandingkan dengan model pembelajaran tipe konvensional. Oleh karena itu, penelitian berjudul "Studi Komparasi Hasil Belajar Siswa dalam Menulis Pantun dengan Menerapkan Cooperative Integrated Reading and Composition (CIRC) dan Konvensional di Kelas VII SMPN 4 Kota Bengkulu" diharapkan dapat menjadi solusi dari siswa yang kemampuan menulis pantunnya masih rendah, sehingga dapat mencetak sastrawan-sastrawan muda di ranah bumi Rafflesia.

\section{METODE}

Metode penelitian ialah cara ilmiah untuk mendapatkan data dengan tujuan dan kegunaan tertentu (Sugiyono, 2008:3). Metode yang akan digunakan dalam penelitian ini adalah metode eksperimen lebih tepatnya Quasi Eksperimental. Quasi Experimental merupakan jenis penelitian yang hampir mirip dengan eksperimen klasik, namun lebih membantu peneliti untuk melihat hubungan kausal dari berbagai macam situasi yang ada. Disebut quasi karena merupakan variasi dari penelitian eksperimen klasik. Menggunakan cara random untuk memilih anggota kelompok, namun memiliki keterbatasan dalam hal pengukuran variabel dependen di awal (pre -test). Data dalam penelitian ini yaitu hasil belajar menulis pantun siswa kelas VII 5 dan kelas VII 6 SMPN 4 Kota Bengkulu sekaligus sebagai sampel penelitian.Pengambilan sampel dilakukan dengan teknik sampel bertujuan (purposive sampling) yang dilakukan pada peserta didik kelas VII SMP Negeri 4 Kota Bengkulu. Sampel dalam penelitian ini diambil berdasarkan kebutuhan yang diperlukan oleh peneliti. Berdasarkan kebutuhan yang dibutuhkan oleh peneliti, sampel yang diambil pada penelitian ini adalah kelas VII 5 dan kelas VII 6. Teknik pengumpulan data pada penelitian ini menggunakan teknik tes. Teknik tes merupakan cara-cara yang digunakan dalam melaksanakan penelitian. Tes dilaksanakan saat pembelajaran selesai. Lembar kerja ini digunakan untuk mengkaji pemahaman siswa mengenai materi yang disampaikan berupa menulis pantun dengan model pembelajaran $\mathrm{CIRC}$ untuk kelas eksperimen dan model pembelajaran konvensional pada kelas kontrol. Alat tes yang digunakan untuk mengukur kemampuan menulis pantun yaitu berupa tugas membuat pantun.

\section{HASIL PENELITIAN DAN PEMBAHASAN Hasil Penelitian}

Hasil penelitian yang telah dilaksanakan mengenai perbandingan antara teknik pembelajaran model Cooperative Integrated Reading and Composition (CIRC) dan teknik pembelajaran model konvensional dalam pembelajaran menulis pantun siswa kelas VII SMP Negeri 4 Kota Bengkulu. Pelaksanaan penelitian ini sudah dilaksanakan pada tanggal 12 April sampai dengan 20 Mei 2018. Penelitian ini 
dilakukan pada dua kelas yaitu kelas VII 5 sebagai kelas eksperimen dan kelas VII 6 sebagai kelas kontrol.Dalam pelaksanaan penelitian di kedua kelas ini, sebelumnya dilakukan pengujian awal (pre -test) setelah itu diakhiri pengukuran variabel akhir (post-test).Data yang diambil dalam penelitian ini, terdiri atas tiga aspek penilaian yaitu, memenuhi syarat pantun, kemenarikan isi pantun, dan diksi.Berikut akan dideskripsikan hasil penelitian mengenai karangan deskripsi menggunakan model pembelajaran CIRC dilihat dari tiga aspek, yaitu memenuhi syarat pantun, kemenarikan isi pantun, dan diksi.

Penerapan CIRC sebagai kelas eksperimen yang dilaksanakan di kelas VII 5. Jumlah siswa yang menjadi kelas eksperimen berjumlah 27 siswa, 10 lakilaki dan 17 perempuan. Pada kelas eksperimen dilaksanakan selama empat kali pertemuan, dimulai pada tanggal 17 April 2018. Hasil dari penerapan teknik pembelajaran model CIRC ini untuk aspek memenuhi syarat pantun yaitu diperoleh skor 2,9 dengan nilai persentase 98\%, aspek kemenarikan isi pantun diperoleh skor 2,6 dengan nilai persentase $88 \%$, dan aspek diksi diperoleh skor 2,5 dengan nilai persentase $83 \%$.

Sedangkan untuk penerapan model konvensional atau kelas kontrol dilaksanakan pada kelas VII 6. Adapun jumlah siswa yaitu 27 siswa yang terdiri dari 15 laki-laki dan 12 perempuan. Hasil dari penerapan teknik pembelajaran model Konvensional ini untuk aspek memenuhi syarat pantun yaitu diperoleh skor 2,7 dengan nilai persentase $90 \%$, aspek kemenarikan isi pantun diperoleh skor 2,3 dengan nilai persentase $76 \%$, dan aspek diksi diperoleh skor 2,1 dengan nilai persentase $71 \%$.

\section{Pembahasan}

Berdasarkan hasil analisis data yang dilakukan peneliti, dilihat dari hasil perhitungan kuantitatif yang dilakukan, bahwa kemampuan menulis pantun siswa setelah menggunakan model pembelajaran CIRC lebih besar nilainya dibandingkan dengan nilai kemampuan menulis pantun dengan model pembelajaran konvensional. Nilai rata-rata siswa dengan menggunakan model pembelajaran konvensional sebesar 79\% dan dengan menggunakan model CIRC nilai siswa sebesar $90 \%$. Jika dilihat dari keseluruhan pada tabel kategori hasil tes menulis pantun, nilai rata-rata siswa dengan menerapkan model pembelajaran CIRC terlihat lebih besar dibandingkan nilai rata-rata siswa yang menerapkan model konvensional.

Pada nilai rata-rata pada aspek memenuhi syarat pantun, kemenarikan isi pantun, dan diksi, setelah menggunakan model CIRC siswa memperoleh nilai ratarata 8,1 yang tergolong ke dalam kategori sangat baik. Sedangkan nilai rata-rata pada aspek memenuhi syarat pantun, kemenarikan isi pantun, dan diksi dengan model konvensional, siswa mendapatkan nilai rata-rata 7,1 termasuk dalam kategor baik, sedikit lebih rendah dibandingkan dengan menggunakan model CIRC.

Pada nilai rata-rata aspek penilaian yang diperoleh siswa untuk menulis pantun menggunakan model pembelajaran CIRC dan model konvensional memiliki perbedaan. Rata-rata aspek penilaian menggunakan model CIRC sedikit lebih besar dibandingkan dengan menggunakan model konvensional. Kemudian, setelah dilakukan uji t-test diperoleh perbedaan yang antara kelas eksperimen dan kelas kontrol. Perbedaan nilai antara kedua kelas ini yakni 9,8 dan diperoleh t-hitungnya yaitu 2,63.

Menurut Tarigan (1994:3), menulis adalah suatu keterampilan berbahasa yang dipergunakan untuk berkomunikasi secara 
tidak langsung, tidak secara tatap muka dengan orang lain. Dalam komunikasi tertulis terdapat empat unsur yang terlihat di dalamnya yaitu: (1) penulis sebagai pesan, (2) pesan atau isi tulisan, (3) saluran atau medium, (4) pembaca sebagai penerima pesan. Menurut konsep ini kegiatan menulis merupakan kegiatan untuk mengungkapkan segala sesuatu yang ada dalam pikiran dan perasaan seseorang kepada orang lain dalam bentuk tulisan.

Melalui penelitian ini, berdasarkan langkah-kangkah analsis data yang telah dilakukan dapat diihat gambaran terhadap masalah yang dibahas dalam penelitian ini sudah terlihat jelas. Pada proses penelitian, untuk mendapatkan hasil penelitian yang diinginkan, peneliti memberikan suatu ulasan kembali tentang materi pembelajaran tentang puisi rakyat yang di dalamnya terdapat materi menulis pantun. Setelah melakukan refleksi dari materi pantun, peneliti memberikan pengarahan kepada siswa mengenai kegiatan pembelajaran yang akan dilakukan. Peneliti menjelaskan bahwa penelitian ini akan dilakukan dua kali setiap kelas baik kelas kontrol maupun kelas eksperimen, yang pertama peneliti memberikan pembelajaran kognitif untuk siswa tentang pantun yang bertujuan agar siswa dapat memahami materi ini dengan efektif dan yang kedua siwa diberikan perlakuan atau treatmen dengan menggunakan model CIRC di kelas eksperimen dan model konvensional di kelas kontrol. Setelah itu siswa diberikan post-test membuat pantun untuk dapat melihat kemampuan hasil belajar siswa di kelas eksperimen dan kelas kontrol.

Hasil analisis data yang dilakukan oleh peneliti dengan menerapkan model CIRC di kelas eksperimen atau VII 5 dan model konvensional di kelas VII 6 SMPN 4 Kota Bengkulu. Memperoleh perbedaan hasil dalam pembelajaran menulis pantun di kelas VII yang tidak terlampau jauh. Dari beberapa model pembelajaran jenis kooperatif, CIRC mempunyai kelebihan dibidang mengkomparasikan antara menulis dan membaca serta ilmu bahasa lainnya. Sedangkan dengan pembelajaran model konvensional yang sering digunakan oleh beberapa guru di kelas, tentu tidak semuanya bisa membuat pembelajaran tersebut efektif. Sebaiknya, semakin variatifnya pembelajaran yang ada, maka harus inovatif pula model pembelajaran yang digunakan. Agar pembelajaran di kelas tidak terkesan monoton dan juga dapat memperbaiki serta memajukan pendidikan di Indonesia.

\section{PENUTUP}

\section{Kesimpulan}

Berdasarkan hasil penelitian dan pembahasan di atas, dapat disimpulkan bahwa hasil perhitungan tes kemampuan menuis pantun siswa menggunakan model pembelajaran CIRC dan menggunakan model konvensional terdapat perbedaan yang signifikan. Adapun kesimpulan dari penelitian ini yaitu:

a. Kemampuan menulis pantun dengan menggunakan model Cooperative Integrated Reading and Compisition (CIRC) memperoleh skor nilai rata-rata sebesesar 90,5 \% terletak pada skala 85 $100 \%$ yang terletak pada kategori persentase sangat baik.

b. Sedangkan untuk pembelajaran menulis pantun dengan model konvensional atau kelas kontrol yang berada pada kelas VII 6 memperoleh skor nilai ratarata siswa sebesar $79,4 \%$ terletak pada skala $75-84 \%$ yang tergolong dalam kategori baik.

c. Setelah dilihat dari uji t-test perbedaan dari model CIRC dengan model konvensional terdapat perbedaan atau rentang nilai 9,8. Pada uji tes diperoleh hasil t-hitung diperoleh 2,63. Hal ini menunjukkan bahwa model pembelajaran model CIRC cukup 
berpengaruh pada hasil kemampuan menulis pantun yang diperoleh siswa di kelas VII SMP Negeri 4 Kota Bengkulu tahun ajaran 2017/2018.

\section{Saran}

Dari hasil penelitian yang diperoleh, maka saran yang dapat peneliti berikan yaitu sebagai berikut:

a. Harapannya guru dapat memberikan inovasi-inovasi kreatif dalam pembelajaran menulis pantun ataupun dalam pembelajaran menulis produk sastra lainnya.

b. Model pembelajaran Coopereative Integrated Reading and Composition (CIRC) merupakan model pembelajaran berkelompok dan terpusat pada siswa. Oleh karena itu, guru diharapkan untuk lebih kreatif dalamm suasana belajar dan tidak hanya menggunakan model pembelajaran konvensional yang dimana guru yang sepenuhnya memegang kendali pembelajaran. Jika hal ini terus terjadi secara berulang, akan berdampak terhadap semangat dan minat belajar siswa yang akan menurun. c. Guru diharapkan dapat menggunakan model pembelajaran CIRC sebagai salah satu model yang inovatif yang sesuai untuk mengembangkan kemampuan membaca dan menulis, serta model ini hanya dapat digunakan khusus dalam pembelajaran seni berbahasa salah satuunya menulis pantun.

\section{DAFTAR PUSTAKA}

Iskandarwassid, Dadang Sunendar. 2010. Strategi Pembelajaran Bahasa. Bandung: Remaja Rosdakarya.

Shoimin, Aris. 2014. 68 Model Pembelajaran Inovatif dalam Kurikulum 2013. Yogyakarta: Ar-Ruz Media.

Sugiyono. 2008. Metode Penelitian Kuantitatif, Kualitatif dan $R$ \& D. Bandung: Alfabeta. . 2013. Metode Penelitian Pendidikan Pendekatan Kuantitatif, Kualitatif, dan R\&D. Bandung : Alfabeta.

Tarigan, Henry Guntur. 2008. Metodologi Pengajaran Bahasa 1. Bandung: Angkasa. 